\title{
INVESTIGACIONES
}

\author{
Luz Dary Arias S. \\ Emma Campo C. \\ Julieta Zuluaga G.
}

\section{APROPOS OF ACCREDITATION: COURSEBOOK EVALUATION AND CULTURE IMPLEMENTATION IN FLC}

For more than four years, the Language Department of Universidad Pedagogica Nacional engaged in the process of designing a new curriculum for the undergraduate language programs. In 1998, the Department finished designing the new curriculum for those programs in order to get their official accreditation. Nowadays, after the new curriculum has been accredited, the teacher staff is working on the design of the programs for each "espacio académico". taking into account some pedagogical, psychological, sociological and curricular referents 1 .

As part of this process of curriculum renovation, each area of the Language Department- Pedagogy, Semiotics and Linguistics, Literature, Foreign Language and Research- is working on the curricular and programmatic bases of every subject that belongs to the corresponding area. The field of Foreign Language English specifically -, is not an exception. Consequently, a selected team of teachers is carrying out the process of stating the corresponding connections between the theoretical foundations established in the curriculum and the new contents that have been set up through the 'know' and 'know how' based on competences.

As such, it is necessary to bear in mind two relevant and influential issues that determine how this bridge is going to be built: a) the evaluation of the coursebooks in terms of a deep analysis of the language materials for English as a foreign language, taking into account the contents for the new curricular approach and $b$ ) the challenge for this particular curriculum, that is to say, the de velopment of the foreign culture in the foreign language classrooms, as the fifth essential element in the teaching-learning of an L2 (the others being the four skills that define a foreing language proficiency).

As the pedagogic referent of the new curriculum states it, the teaching process must be that which creates the condition for the production, reproduction and transformation of culture based on the knowledge of one's culture and the knowledge of other cultures and their exchange and on the pedagogic discourse whose function is as a producer and transformer of culture. (Proyecto de Innovación de los Planes de Estudio, Language Department, November,1999:8);

\footnotetext{
${ }_{1}^{*}$ Profesoras del Departamento de Lenguas Universidad Pedagógica Nacional

These referents are well supported in the document published by the Language Department entitled “Proyecto de Renovación de los Planes de Estudio”, noviembre, 1999.
} 
and, by the same token, "...el conocimiento de nuevos conceptos acerca del aprendizaje de una lengua extranjera nos permite apropiarnos de su significación cultural y, en consecuencia, nos posibilita la trascendencia del saber acerca de reglas y nomas hacia la realización de tal saber en contextos cognitivos particulares $y$, por ende, cifrados por la presencia de actitudes y valores especificos." (ibid.: 9). To begin with, we are going to discuss and establish the appropriate parameters to evaluate a coursebook and afterwards, we are going to state some guidelines to bring the cultural matter to the foreign language classroom.

In the field of language teaching we have become accustomed to regular revolutions as one syllabus model gives way to another and as methodological innovations supplant the practices of the past. It is how we can find the process and product oriented syllabus taxonomy (Nunan 1988), Structural and Functional Syllabus (Cunningsworth 1984) and (Dubin and Olshtain 1986) with their four major kinds of syllabuses. Furtherm ore, we may talk about different methodological innovation as follows: teacher-leamer's role, views on how language is leamed and how it is best taught as well as learner's needs in the process of teaching-learning an L2 (Cunnings worth 1996).

On the other side of the spectrum, there have been a great amount of surveys into what EFL/ESL teachers want from their training and it has been discovered that one of the most important selected items is 'material selection and evaluation'. These surveys have not explored the reasons for the importance of this item, but it is easy to see why material evaluation and selection should be ranked so highly. Materials are not simply the everyday tools of the language teacher. As Hutchinson (1987:37) states, they are an embodiment of the aims, values and methods of a particular teaching-learning situation. As such, the selection of materials probably represents the simple most important decision that a language teacher-analyst has to make.

However, what criteria do textbook evaluators have for selecting materials? Cunningsworth (1996) affims that there are different criteria to take into account when selecting your cours ebooks, i.e. try out or pilot the material before adopting it, to seek the opinions of practicing teachers both within and outside the institution, students' views on the usefulness of the material and, finally, where there is no opportunity to talk to people who have actually used the material, and where piloting is feasible, as for example, when setting up a completely new teaching program, then a detailed analysis of the material is the best way of becoming familiar with it. Besides that, there are practical factors to consider such as price, availability, length of the course and so on. Notwithstanding, they are only very crude indicators of suitability, and while such general features of a coursebook must be considered, the process of material evaluation only takes a real value when we carry out a very deep and conscious analys is of what the coursebook actually offers. Unfortunately, it is not always possible to gather this information from a publisher's own description of the materials and therefore a more systematic framework for the analysis of language teaching materials must be 
followed, since we need to be able to examine the implications of using a set of materials for the classroom work and thus come to grounded opinions about whether or not the methodology and content of the materials are appropriate for our particular language teaching context.

As Littlejohn (1998:191) points out, "we also need to be able to test out the claims now being made for materials: Do they truly help to de velop autonomy? Do they truly in volve problem solving? Are they truly learner centered? We need, in short, a means of looking inside the Trojan horse to see what lies within". Our concern, then, is with the analysis of language materials 'as they are', that is to enable a close analysis of materials as a support to materials evaluation according to the specific language teaching context we are dealing with.

When talking about analyzing materials, one of the most obvious sources is the large number of frameworks which exist to evaluate coursebooks, such as: Williams, 1983; Cunningsworth, 1984, 1996; Doughill, 1987; Nunan, 1991; Hutchinson, 1987 and Harmer, 1991. However, one of the principal problems we face in using these frameworks is that they usually involve making general, impressionis tic judgements on the materials, rather than examining in depth what the materials contain, (Littlejohn, ibid:191). What is required then is a framework which separates assumptions about what is desirable from an analysis of the materials.

It is how, Andrew Littlejohn (1998) presents a new and more complete framework for analyzing coursebooks which aims at allowing the materials speak for themselves and helping teacher-analysts look closely into materials before coming to their own conclusions about the desirability or otherwise of the materials. This suggests three separate questions that we need to consider carefully:

1. What aspects of materials should we examine?

2. How can we examine materials?

3. How can we relate the findings?

Taken from Littlejohn, 1998:192

\section{A GENERAL FRAMEWORK FOR ANALYZING MATERIALS}

\section{What aspects of materials should we examine?}

Bearing in mind that our focus here is on materials as a pedagogic device -that is an aid to teaching and leaming a foreign language- we will limit the focus to aspects of methodology_of materials and their content. To this end, we will consider the framework proposed by Littlejohn (ibid.) which draws extensively on these analyses of language teaching previously done by authors like Mockey (1965), Corder (1973), Breen and Candlin (1987) and Richards and Rogers (1986). This 
framework attempts to provide a more comprehensive list of as pects which from a pedagogic point of view need to be taken into account.

\section{PUBLICATION}

1. Place of the leamer's materials in any set of materials

2. Published form of the leamer's materials

3. Subdivision of the learner's materials into sections

4. Subdivision of sections into subs ections

5. Continuity

6. Route

7. Access

\section{DESIGN}

1. aims

2. Principles of selection

3. principles of sequencing

4. Subjectmatter and focus of subject matter

5. Types of learning/teaching activities:

-what they require the learner to do

-manner in which they draw on the leamer's process competence (knowledge, abilities, affects, skills)

6. Participation. Who does what with whom

7. Learner roles

8. Teacher roles

9. Role of materials as a whole

Figure 1 Aspects of an analysis of language teaching materials.

Taken from Littlejohn, 1998:193

This framework consists of two sections: Publication and design. The first one refers to the tangible or physical aspects of the materials and how they appear on a complete set or book. The second one relates to the thinking underlying the materials. This will involve consideration of areas such as the apparent aims of the materials, how the tasks, language and content in the materials are selected and the nature and focus of content in the material.

Also of central importance in this will be the nature of the teaching/learning activities which are suggested by the materials. An analysis of the materials will have to focus closely on what precisely learners are asked to do and how what they do relates to what Breen and Candlin (1987) call leamer's process competence. It means to analyze how it is presented- kind of syllabus and which are the aspects of language content they take into account, e.g. grammar, vocabulary, phonology, management of discourse, style and appropriacy and variety of the foreign language (Cunningsworth,1996:31). Taken together, the 
areas listed above should provide a comprehensive coverage of the methodological and content aspects of any set of materials.

Now we will turn to the second question of our analysis:

\section{How can we examine the materials?}

As we can see in the framework set out in the previous section, there are some aspects that will be relatively easy to identify (for example, published form of the materials) whilst others appear more abs tract and difficult to es tablish (for example, aims and learner/teacher roles), since some of the listed aspects will involve examining different parts of the materials before coming to a general conclusion. On its own, and according to Littlejohn, (ibid.: 196) "therefore, the framework has very limited use since it is not able to guide the teacher-analyst in examining the materials to any depth. The principal problem is that some aspects in the framework actually entail coming to a conclusion about other aspects in the framework. This means that in building up an analysis of a set of materials, teacher-analysts will not have to examine different sections of the material, but, more importantly, move through different levels of analysis, making more and more inferences - and subjective judgements - as they move from a consideration of the more easily identifiable aspects to the more abstract and complex. Figure 2 outlines the levels which may be involved, from the most objective (what is physically there in the materials, Level 1), through the deductions about the demands lightly to be made of teachers and learners (Level 2), to conclusions about the apparent underlying principles and philosophy of the materials (Level 3)."2

\section{LEVELS OF INFERENCE}

'what is there'

\section{LEVEL 1}

\section{Publication}

Place of leamer's materials in set

Published form of leamer's materials

Subdivision of learner's materials

Subdivisions of sections into subsections

Continuity

Route

Route

Access

Design

\footnotetext{
${ }^{2}$ If it is of the reader's interest, Andrew Littlejohn (1998) presents a very deep explanation of how to go through each one of these levels of analysis to evaluate coursebooks.
} 


\title{
LEVEL 2
}

'what is required of users'
Subjectmatter and focus

Types of teaching/learning activities

Participation: who does what with whom

\section{LEVEL 3}

\section{Aims}

'What is implied'

\author{
principles of selection \\ principles of sequencing \\ Teacher roles \\ Learner roles (class room) \\ Learner roles (in learning) \\ Role of materials as a whole
}

Figure 2 Levels of analysis of language teaching materials.

Finally, we address to our third question:

\section{How can we relate findings to our own teaching contexts?}

As we can observe, taken together the three levels of analysis for examining a set of materials, we are equipped with a very powerful means of revealing the underlying nature of materials. As Littlejohn states, they provide a thorough bas is for testing out how far both aims and claims in the materials are met and thus will aid anyone involved in their design and use to take more control of the materials with which they are in volved. At the design stage of materials, the greater depth of understanding that the framework will provide should aid material designers in identifying any mismatches between aims and the actual nature of the materials they are working on. Similarly, at the implementation stage of classroom use, the framework can potentially help teachers and students to examine materials and to decide on further courses of action. Whilst, however, the framework will reveal the underlying nature of materials, a next step towards fully evaluating them ( that is, deciding their relative pedagogic worth) will in principle require an equally careful prior analysis of what teachers/students/institutions expect from materials, to see how far the two (that is, materials and expectations) relate to or match each other" (Littlejohn, ibid.: 202). Figure 3 provides a brief outline of how this may work. 


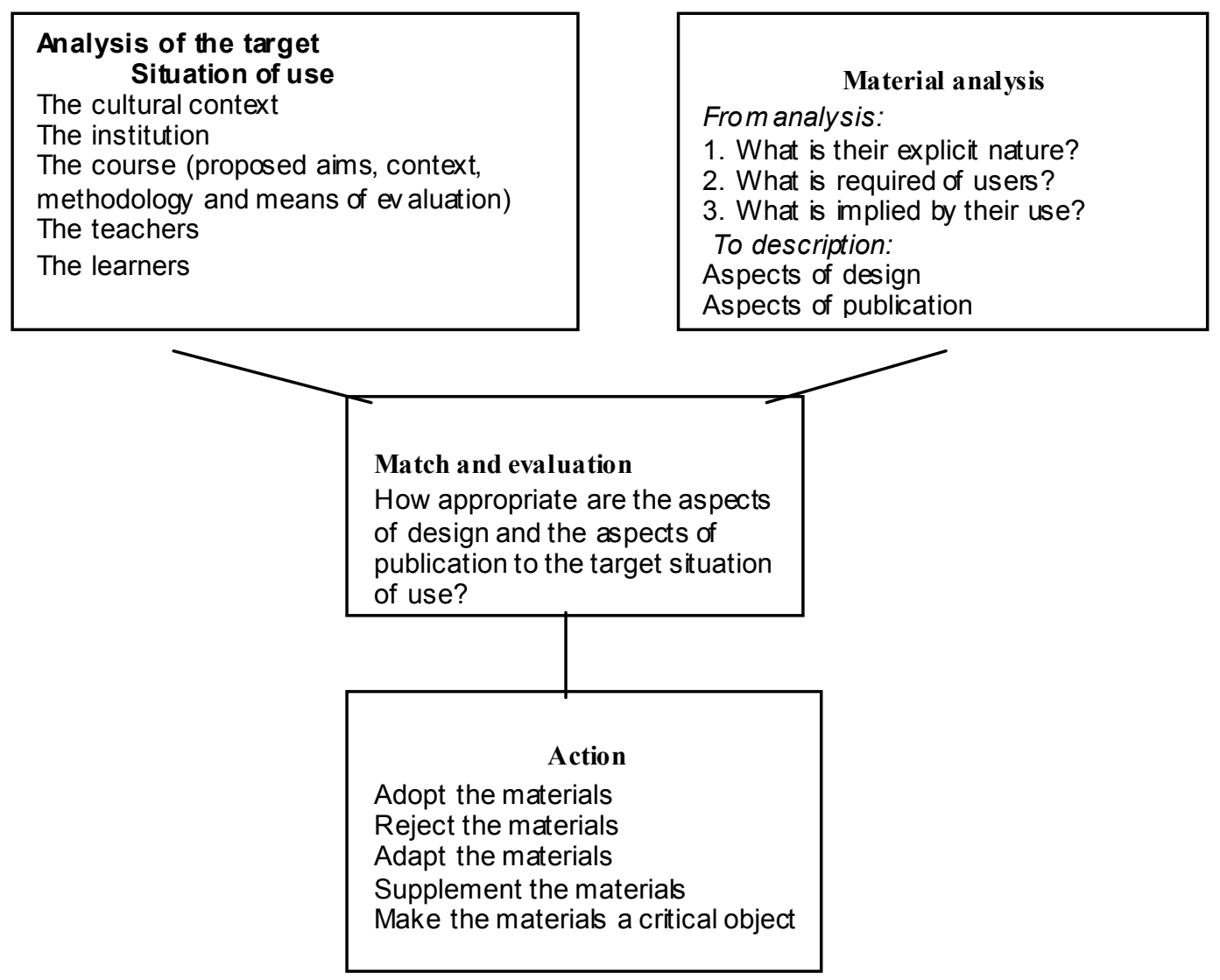

Figure 3 Establishes a clear distinction between an analysis of the materials of the proposed situation of use, the process of matching and evaluation and sub sequent action.

Matching and evaluation can then follow in which an evaluator would need to set out precisely which as pects of the materials are appropriate or inappropriate and why. In practice, this, for example, might involve a group of teachers first, identifying what they require of materials and these may therefore be analyzed in detail so that the extent of match between the teacher's expectations and the nature of the materials can be seen. The final stage in Figure 3 , action, involves evaluators in making decisions over what to do next in the light of matching and evaluation. A number of conventional responses are listed here, but there is also the possibility of adopting a set of materials in order to make it an object of critical focus.

By checking the processes of material analysis, evaluation and implementation in this way, the 'hidden assumptions' in the evaluation guides can be lessened. "In its place, an open procedure is proposed in which evaluators can investigate the internal character of the materials and the situation in which they will be used, make clear their own personal judgement and act accordingly. In this way, the analytical framework may be seen as potentially empowering educational 
administrators, teachers, learners and others to voice their needs and to take more control over the materials with which they are involved". (Littlejohn, ibid.:205)

Taking into account these needs Littlejohn talks about, another aspect to consider when evaluating teaching materials is the way they deal with culture, that is, the development of foreign culture in foreign language classrooms. The study of culture as the fifth element in the teaching-learning process of foreign language has been a focus of attention from a variety of disciplinary perspectives for many years. Linguists, anthropologists, sociologists, psychologists and others have sought to unders tand whether and how cultural factors influence as pects of human behavior such as perception, cognition, language and communication. Within language teaching, cultural factors have occasionally attracted the interest of both, theoreticians and practitioners. However, it was Robert Lado who suggested that the cultural systems in the native culture could be compared to the ones in the target culture and that they could serve as a source of transfer or interference when learning a second or foreign language.

Looking back the years to get an idea of how the study of the relationship between language and culture started, linguists like Sapir (1920s) and Whorf (1950s) concluded that language and the culture of a group of people must be analyzed together. Then, in the 70s, Geertz (1973) noted that language and its uses were an important part of human behavior that represents symbolic action according to the social structure and interaction given within the group. Besides, Hymes (1971) concluded that "speech events are governed by social and linguistic noms for the use of discourse as well as communicative content, form, setting and goals of a speech community (Hinkel, 1999:4). Despite these findings, in that time the relationship between language and culture was not relevant to second or foreign language teaching.

Later on, in the 1980s, the study of culture in second language focused on body language, eye contact, and generally in behavioral as pects. Furthermore, Damen's work (1987) emphasized on the urgency for language teachers to become ethnographers of their students' own cultures. In the 1990s, several linguists and researchers concluded that cultural awareness and the learning of a second culture could only help the attaining of a second language proficiency. Kramsch (1991) noted that second and foreign language learners necessarily become learners of the second culture because a language can not be learned without an understanding of the cultural context in which it is used.

In this current understanding of the place of culture in second and foreign language pedagogy and leaming, the works of Michael Byram (1989), Buttjes and Byram (1991) and Byram and Morgan ( 1994) have played a prominent role since it was observed not only that culture represents hidden curriculum when teaching an L2, but also that the analysis of cultural as pects of languages enhances the language awareness of learning and contributes to the learner consciousness of language and proficiency as a whole. That is to say, cultural learning has to take place as an integral part of language leaming and viceversa. 
When addressing the cultural aspect, we have to take into account two issues: first of all, what we have to work of culture and second, which parameters we have to consider to evaluate this element in the coursebooks that are followed in any foreign language department. To deal with the first aspect, it is necessary to bear in mind a variety of aspects such as the influence of culture on aspects of interaction and learning that often appear mundane, and as Hinkel, 1999:10 states "in interactions among members of different cultures, divergent concepts of appropriate behaviors and meaning interpretations can affect participants' conduct in social context".

Moreover, Bouton (in Hinkel, ibid.) investigates the second matter, leaming of meaning and conversational implications in $L 2$ interactions. He points out that culturally defined contexts of interactions and the role of participants underlie the learners' ability to interpret conversational implicature and that members of different cultures appear to have diverse expectations of their interactional roles. On the other side, it is quite important to talk about the third aspect, the influence of culture on writing and learning to write in a foreign language. Al this, looking at writing as representations of social and cultural values that differ among communities of language speakers and language learners. Kachru and Harklau (in Hinkel, ibid.).

Another element to develop in teaching culture is the relationship between culture and language teaching materials and methods taking into account the pragmatic competence of second language learners, e.g. communicative competence (Hymes) and speech act theory (Austin and Searle) in order to heighten teacher and learner awareness of the influence of culture on second language teaching and learning Rose and Judd (Hinkel, ibid.). The last issue to be considered is the cultural content of the foreign language. Gail Robins on (1985) reports that when teachers are asked what culture means to them, the most common responses given fall into three interrelated categories. Namely, products, ideas and behaviors. The broadening of 'little C' (behavior culture) can be expressed through the following diagram: 


\section{ELEMENTS OF CULTURE}

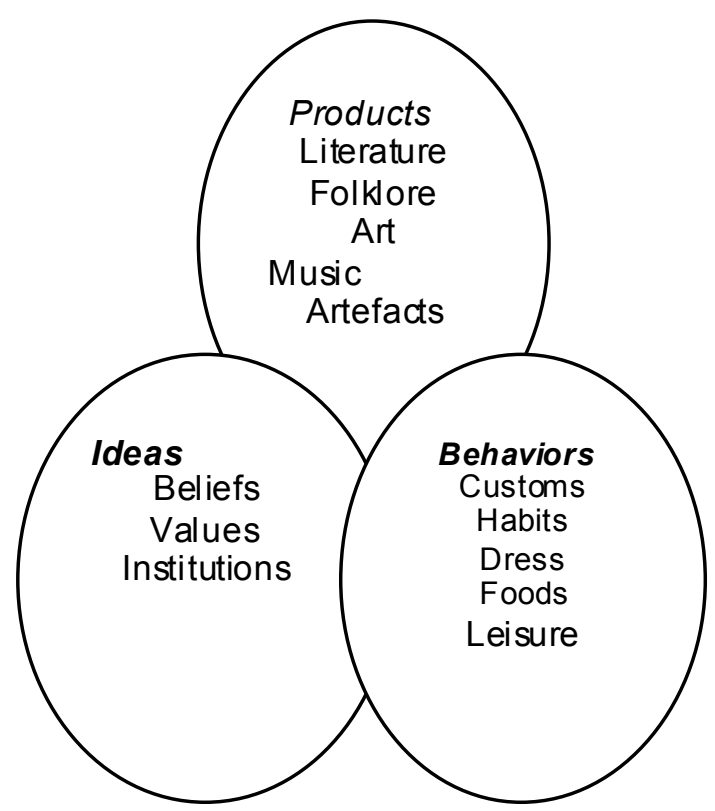

Figure 4 The broadening of 'Little C' (behavior culture) Taken from Cultural Awareness, 1993:7

Notwithstanding, because culture and its facets are often difficult to define and describe, little applied linguistic research has been carried out to deal with the manifestation of culture in language use, (Hinkel, ibid.: 32). As an outcome, few ESL and EFL coursebooks and pedagogical approaches address second or target culture and the task of developing the necessary teaching materials is often left to the class room instructors, and this fact takes us to the second issue that is which parameters we have to bear in mind to evaluate this element in the coursebooks. As Cortazzi, (1999:196) affirms: "The extent and quality of inclusion are sometimes assessed using textbook evaluation checklists, but some published checklists do not mention culture, others involve cultural content in terms of leamers' attitudes, values and feelings; others draw attention to stereotypes of races and cultures in textbooks; others mention varieties of target cultures. Other checklists whether social realities like unem ployment, poverty, are omitted.

To overcome this, Byram's list - considered one of the most thorough- focuses on cultural content and analyzes the extent and manner in which a coursebook includes an emphasis on each of the areas shown in figure 5 . 


\section{Criteria for textbook evaluation Focus on cultural content}

- Social identity and social groups

(social dass, regional identity, ethnic minorities)

- Social interaction

(differing levels of formality; as outsider and insider)

- Belief and behavior

(moral, religious beliefs; daily routines)

- Social and political institutions

(state institutions, health care, law and order, social security, local government)

- Socialization and the life cycle

(families, school, employment, rites of passage)

- National history

(historical and contemporary events seen as markers on national identity)

- National geography

(geographic factors seen as being significant by members)

- Stereotypes and national identity

(What is "typical", symbols of national stereotypes)

Figure 5 Criteria for textbook evaluation.

Taken from Hinkel, 1999:203

\section{Evaluating treatment of cultural con tent in textbooks}

- Giving factually accurate and up-to-date information

- Avoiding (or realizing) stereotypes by raising awareness

- Presenting a realistic picture

- Being free from (or questioning) ideological tendencies

- Presenting phenomena in context rather than as isolated facts

- Explicitly relating historical material to contemporary society

- Making it clear how personalities are products of their age

Figure 6 Evaluating the treatment of cultural content of textbooks. Taken from Hinkel, ibid.: 203

The last matter to be accounted for when evaluating the cultural aspect in a coursebook is the kind of culture it deals with, since EFL/ESL textbooks reflect not only the target culture, but als o source cultures and international cultures. Source culture, considered as the learner's own culture, target culture, defined as the culture where the target language is used as a first language, e.g. English in the United States, Canada, England, Australia. And, finally, international culture which 
refers to cultures in English or non-English speaking countries where English is not a first language but rather a means of communication of several cultures ${ }^{3}$.

Although linguists have come to the conclusion that cultural variation is close to language use, pedagogy rarely addresses the influences of culture on language learning and teaching. As we specified at the beginning of this paper, cultural learning must be included in the curriculum as an integral element of language learning, and strictly evaluated in the coursebooks we are working on. The challenge, then is to start searching for the appropriate techniques and strategies to bring this theory into practice in our real foreign language settings, what should be a matter of research in the Language Department of Universidad Pedagogica Nacional.

Finally, after having discussed the parameters to evaluate coursebooks and the necessity to develop the foreign culture in the foreign language classrooms, it is of great importance to say that selecting teaching materials is often not an easy task but we hope that this article -although we recognize that we did not go deeper in each one of these guidelines due to the limitations of this kind of publications - will help make it a little easier and will help ensure that the choices made are the best possible ones to match the theoretical foundations of the new curriculum and the new contents that have been set up in the new programs of the Language Department of Universidad Pedagógica Nacional. We expect that further reflection and study will be done in this area of pedagogy and foreign language teaching.

\section{REFERENCES}

Breen. M. P. and C. N. Candlin (1987). Which materials?: A Consumer's and Designer's guide. In Sheldon, 1987.

Byram, M (1991). Teaching culture and language: Towards an integrated model. In D. Buttjes and M. Byram (Eds.), Mediating Languages and Cultures: Towards an intercultural theory of Foreign Language Education (pp. 17-32). Clevedon, UK: Multilingual matters.

Byram, M. (1989). Cultural Studies in Foreign Language Education. Clevedon, UK: Multilingual Matters.

Byram, M. and Morgan, C. (1994) Teaching and Leaming Language and Culture. Clevedon, UK: Multilingual matters.

Cortazzi, Martin and Jin Lixian (1999). Cultural mirrors: Materials and Methods in the EFL classroom. In Eli Hinkel (Ed.), Culture in Second Language Teaching and Learning (196-219). Cambridge: Cambridge university Press.

Cunningsworth, Alan (1984). Evaluating and Selecting EFL Materials. London: Heinemann International.

Cunningsworth, Alan (1995). Choosing your coursebooks . Oxford: Heinemann.

${ }^{3}$ A complete review of this taxonomy and how each one is put into practice in the coursebooks are stated by Cortazzi and Jin in Culture in Second Language Teaching and Learning, 1999. 
Damen, L. (1987). Culture Learning: The Fifth Dimension in the Language Classroom. Reading, MA: Addison-Wesley.

Doughill, J. (1987). Not so obvious. In Sheldon. 1987.

Dubin, Fraida and Olshtain (1986). Course Design. Cambridge: Cambridge University Press.

Geertz, C. (1973). The interpretation of Cultures. New York. Basic Books.

Harmer, J. (1991). The Practice of English Language Teaching, $2^{\text {nd }}$ edition. Longman.

Hutchinson, Tom (1987). Interactive view of materials evaluation. In ELT textbooks and materials. Oxford: Modern English Publications .

Kramsch, C. (1993a). Context and Culture in language Teaching. Oxford: Oxford University Press.

Littlejohn, Andrew (1998). The Analysis of Language Teaching Materials. In Brian Tomlinson (Ed.) Materials Development in Language Teaching (190-216). Cambridge : Cambridge university Press.

Nunan, David (1988). Syllabus Design. Oxford: Oxford University Press.

Nunan, David (1991). Language Teaching methodology: A textbook for teachers. Prentice Hall.

Proyecto de innovación de los Planes de Estudio. Equipo profesoral del Departamento de Lenguas. Coordinadores del equipo: Angela Camargo y José I. Correa. Noviembre de 1999.

Robins on, G. (1985). Crosscultural Understanding. New York: Prentice Hall.

Sapir, E. (/1921/ 1961). Culture, language and Pers onality. Berkeley: University of Califomia Press.

Tomalin, Barry and Stempleski Susan (1994). Cultural Awareness. Oxford: Oxford University Press. 